Article

\title{
Coupled Substitutions of Minor and Trace Elements in Co-Existing Sphalerite and Wurtzite
}

\author{
Allan Pring ${ }^{1, *}$, Benjamin Wade ${ }^{2}$, Aoife McFadden ${ }^{2,3}$, Claire E. Lenehan ${ }^{1}$ and Nigel J. Cook ${ }^{4}(\mathbb{C}$ \\ 1 College of Science and Engineering, Flinders University, Adelaide 5001, South Australia, Australia; \\ claire.lenehan@flinders.edu.au \\ 2 Adelaide Microscopy, The University of Adelaide, Adelaide 5005, South Australia, Australia; \\ benjamin.wade@adelaide.edu.au (B.W.); aoife.mcfadden@adelaide.edu.au (A.M.) \\ 3 Flinders Microscopy, Flinders University, Adelaide 5001, South Australia, Australia \\ 4 School of Chemical Engineering and Advanced Materials, The University of Adelaide, Adelaide 5005, \\ South Australia, Australia; nigel.cook@adelaide.edu.au \\ * Correspondence: allan.pring@flinders.edu.au; Tel.: +618-8201-5570
}

Received: 28 November 2019; Accepted: 6 February 2020; Published: 9 February 2020

\begin{abstract}
The nature of couple substitutions of minor and trace element chemistry of expitaxial intergrowths of wurtzite and sphalerite are reported. EPMA and laser ablation inductively coupled plasma mass spectrometry (LA-ICP-MS) analyses display significant differences in the bulk chemistries of the two epitaxial intergrowth samples studied. The sample from the Animas-Chocaya Mine complex of Bolivia is Fe-rich with mean Fe levels of $4.8 \mathrm{wt} \%$ for wurztite- $2 \mathrm{H}$ and $2.3 \mathrm{wt} \%$ for the sphalerite component, while the sample from Merelani Hills, Tanzania, is Mn-rich with mean Mn levels in wurztite- $4 \mathrm{H}$ of $9.1 \mathrm{wt} \%$ and for the sphalerite component $7.9 \mathrm{wt} \%$ In both samples studied the wurtzite polytype is dominant over sphalerite. LA-ICP-MS line scans across the boundaries between the wurtzite and sphalerite domains within the two samples show significant variation in the trace element chemistries both between and within the two coexisting polytypes. In the Merelani Hills sample the $\mathrm{Cu}^{+}+\mathrm{Ga}^{3+}=2 \mathrm{Zn}^{2+}$ substitution holds across both the wurztite and sphalerite zones, but its levels range from around $1200 \mathrm{ppm}$ of each of $\mathrm{Cu}$ and $\mathrm{Ga}$ to above $2000 \mathrm{ppm}$ in the sphalerite region. The $2 \mathrm{Ag}^{+}+\mathrm{Sn}^{4+}=3 \mathrm{Zn}^{2+}$ coupled substitution does not occur in the material. In the Animas sample, the $\mathrm{Cu}^{+}+\mathrm{Ga}^{3+}=2 \mathrm{Zn}^{2+}$ substitution does not occur, but the $2(\mathrm{Ag}, \mathrm{Cu})^{+}+$ $\mathrm{Sn}^{4+}=3 \mathrm{Zn}^{2+}$ substitution holds across the sample despite the obvious growth zoning, although there is considerable variation in the $\mathrm{Ag} / \mathrm{Cu}$ ratio, with $\mathrm{Ag}$ dominant over $\mathrm{Cu}$ at the base of the sample and $\mathrm{Cu}$ dominant at the top. The levels of $2(\mathrm{Ag}, \mathrm{Cu})^{+}+\mathrm{Sn}^{4+}=3 \mathrm{Zn}^{2+}$ vary greatly across the sample from around $200 \mathrm{ppm}$ to $8000 \mathrm{ppm} \mathrm{Sn}$, but the higher values occur in the sphalerite bands.
\end{abstract}

Keywords: wurtzite; sphalerite; trace element substitution; Animas; Merelani Hills

\section{Introduction}

Sphalerite, the cubic close packed ( $c c p)$ form of $\mathrm{ZnS}$ is the most abundant zinc mineral in the crust. In addition to being the principal ore of zinc, sphalerite is an important source of a number of other technologically important elements, including, Ga, Ge, In, and Cd. ZnS also occurs as a family of hexagonal closed packed ( $h c p$ ) modifications (polytypes), known as wurtzite [1]. The wurtzite form of $\mathrm{ZnS}$ is apparently much rarer in nature than sphalerite, but may often be overlooked as ZnS is usually assumed to be sphalerite. Based on visual inspection in reflected light, wurtzite and sphalerite are indistinguishable, but can be readily differentiated in transmitted light with crossed polars [2].

The phase relations among the ZnS polytypes have been a matter of considerable debate for many years [3-6]. Sphalerite will transform to wurtzite when heated to around $1000^{\circ} \mathrm{C}$. Allen and 
Crenshaw [7] reported the transformation occurs at $1020^{\circ} \mathrm{C}$ at 1 atm $\mathrm{H}_{2} \mathrm{~S}$, but subsequent researchers reported different inversion temperatures [8-11]. The transition temperature is reported to be lowered significantly by substitution of Fe, Mn, and Cd [12,13]. Sphalerite and wurtzite are essentially hydrothermal minerals generally forming at much lower temperatures, e.g., in Mississippi Valley-type deposits [2]. As far back as 1934, it was proposed that stabilization of the sphalerite was linked to an excess of sulfur, and wurtzite to sulfur deficiency [14]. Pankratz and King [15] published very accurate analyses of synthetic sphalerites and wurtzites showing that the M:S ratio for sphalerite of down to 0.997 and for wurtzite up to 1.002. Scott and Barnes [16] demonstrated by hydrothermal experiments that the crystallization of $\mathrm{ZnS}$ in either the sphalerite form or the wurtzite form was dependent on the sulfur fugacity, $f S_{2}$, with the formation of the wurtzite polytypes restricted to low $f S_{2}\left(\sim 10^{-20}\right)$.

The major divalent impurities in $\mathrm{ZnS}, \mathrm{Fe}, \mathrm{Mn}$, and $\mathrm{Cd}$, are said to be all more soluble in wurtzite than sphalerite and, therefore, stabilize wurtzite relative to sphalerite under a given set of conditions $[12,13,16]$. Lepetit et al. [17] showed that the upper solubility limit of Fe in sphalerite has a strong dependence on $f S_{2}$, more than doubling from a maximum of $21 \mathrm{~mol} \% \mathrm{FeS}$ to $52 \mathrm{~mol} \%$ with increase in $f S_{2}$. Knitter and Binnewies [18] studied phases in the system MnS-ZnS, using vapor transport growth methods, and found that at compositions $\geq 8 \mathrm{~mol} \% \mathrm{Mn}$ substituting for Zn, the structure switched from the sphalerite to the wurtzite form. The sphalerite-wurtzite boundary would be displaced by solid solution of these components toward higher $f S_{2}$, increasing the temperature range over which wurtzite is stable [16].

A number of minerals and compounds occur in both wurtzite and sphalerite structural forms (the names in italics indicate the structure-type rather than the named minerals). For example there are wurtzite and sphalerite forms of AgI (iodargyrite and miersite) and of CdS (greenockite and hawleyite). In these cases, the wurtzite form is more common in nature than the sphalerite form. Iron sulfide, FeS, in addition to troilite, which has the NiAs structure, occurs in meteorites as rudashevskyite (sphalerite) and bueseckite (wurtzite) and MnS occurs as browneite (sphalerite) and rambergite (wurtzite) in addition to the much more abundant alabandite $(\mathrm{NaCl})$ form. O'Keefe and Hyde [19], pointed out that in compounds that only have a wurtzite form and no sphalerite analogue, such as zincite $(\mathrm{ZnO})$, the cation-cation distances are close to the sum of the non-bonded radii. That is, the wurtzite form can be stabilized over the sphalerite form by cation-cation repulsions and this is consistent with wurtzite being sulfur-deficient and sphalerite cation-deficient.

The minor and trace element chemistry of sphalerite has been the subject of much study, as has the structural nature of the coupled substitutions involved [20-28], but a similar study of wurtzite is lacking. In many of the above compositional studies the structural form of the ZnS were not confirmed by X-ray diffraction methods as sphalerite and some of the samples maybe have actually been intergrowths of polytypes. Common substitutions include direct substitutions of divalent cations $\left(\mathrm{Cd}^{2+}, \mathrm{Mn}^{2+}, \mathrm{Fe}^{2+}\right)$ for $\mathrm{Zn}^{2+}$, substitutions involving the coupling of mono- and trivalent cations for divalent $\mathrm{Zn}$, e.g., $\mathrm{Cu}^{+}+\mathrm{In}^{3+}=2 \mathrm{Zn}^{2+}$, or $\mathrm{Cu}^{+}+\mathrm{Ga}^{3+}=2 \mathrm{Zn}^{2+}$, and more complex mechanisms such as $2(\mathrm{Cu}, \mathrm{Ag})^{+}+\mathrm{Sn}^{4+}=3 \mathrm{Zn}^{2+}$ but there are many others that have been reported or proposed [19,25]. Due to its apparent relative rarity in nature, and when present, its intimate intergrowth with sphalerite, conducting minor and trace element studies of wurtzite can be quite challenging. Because of stacking disorder in wurtzite, X-ray diffraction patterns of wurtzite tend to give considerably lower intensity peaks than sphalerite. Furthermore, quantitative phase analyses of sphalerite-wurtzite intergrowths by powder X-ray diffraction do not correlate well with the optical measurements (see below).

To establish whether cation chemistry changes are associated with the switch between polytypes in nature, it is important to analyze across the boundaries between epitaxial intergrowths of sphalerite and wurtzite. The minor and trace element chemistries of co-existing sphalerite and wurtzite, particularly coupled substitutions should thus reflect changes in fluid composition during growth, but may also highlight crystal-chemical controls. To explore the relationship between the chemistry and structure among ZnS polytypes, it is necessary to analyze specimens which represent coherent intergrowths between sphalerite and wurtzite. In this study, we examine the minor and trace element chemistry 
of such intergrowths from two well-known wurtzite occurrences where epitaxial intergrowths with sphalerite occur.

\section{Materials and Methods}

The specimens analyzed in this study are from the collection of the South Australian Museum, Adelaide, Australia: (i) a banded epitaxial intergrowth of wurtzite- $2 \mathrm{H}$ and sphalerite some $10 \mathrm{~mm}$ thick from the Animas-Chocaya Mine complex, Quechisla district, Bolivia (SAM G33739; henceforth denoted "Animas") (Figure 1); and (ii) a crystal of wurtzite $-4 \mathrm{H}$ with epitaxial zones of sphalerite from the Merelani Hills tanzanite deposit, $50 \mathrm{~km}$ SE of Arusha, Manyara Region, Tanzania (SAM G34171) (Figure 2).

The Animas-Chocaya complex lies toward the southern end of the Bolivian tin-silver belt in the South Eastern Andes of Bolivia. The Miocene mineralization occurs in hydrothermal vein systems associated with quartz latite and dacite stocks, and dykes in sediments of Ordovician age [29,30]. Fluid inclusion studies give temperatures of 170 to $270{ }^{\circ} \mathrm{C}$ with salinities of between 3.7 and $5.2 \mathrm{wt} \%$.

The local geology of the Merelani Hills tanzanite deposit, Tanzania, is summarized by Olivier and Wilson et al. [31,32]. It is a complex deposit, hosted in high temperature $\left(100{ }^{\circ} \mathrm{C}\right)$ high pressure (10-12 kbar) metamorphosed limestones with bands of graphite, quartz-feldspathic, and kyanite gneisses. An unusual suite of sulfide minerals occurs in the deposit, including what are considered to be the world's largest and finest wurtzite crystals [33]. Wurtzite occurs as the $4 \mathrm{H}$ polytype epitaxially intergrown with sphalerite, with both forms of $\mathrm{ZnS}$ being Mn-rich within the deposit.

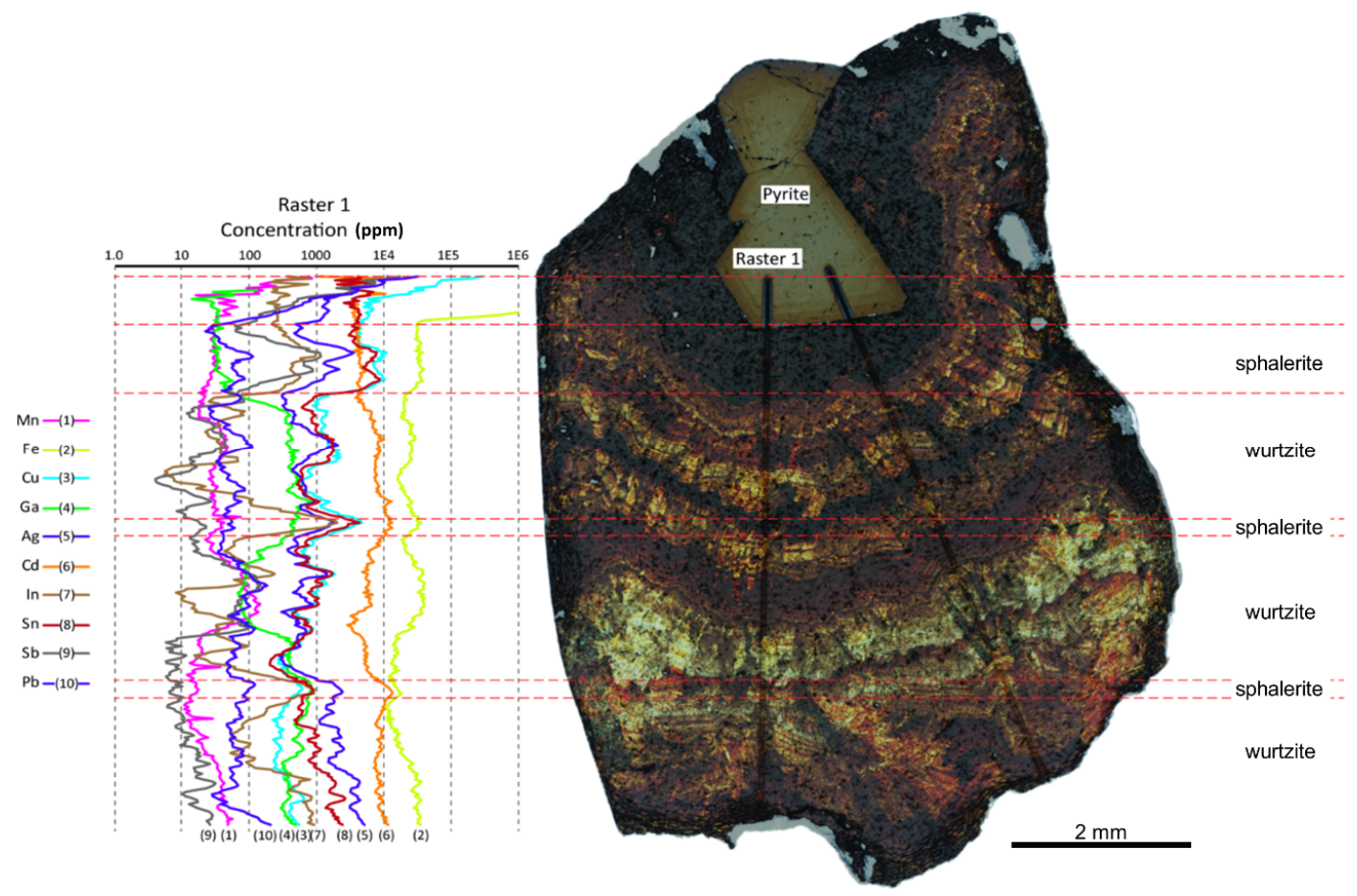

Figure 1. Photomicrograph of the sample from Animas-Chocaya Mine, Bolivia (G33739) displaying growth zoning. The image is an overlay of a reflected light image and a transmitted light image taken under crossed nicols. The bottom of the sample shows the pyrite matrix surrounded by a region of sphalerite (black). The remainder of the sample is wurtzite-2H (brown to pale yellow) but with thin bands of sphalerite (black). The position of the two LA-ICP MS line scans are indicated. A log plot showing the variations in concentrations of minor and trace elements along Line scan 1 is superimposed. 


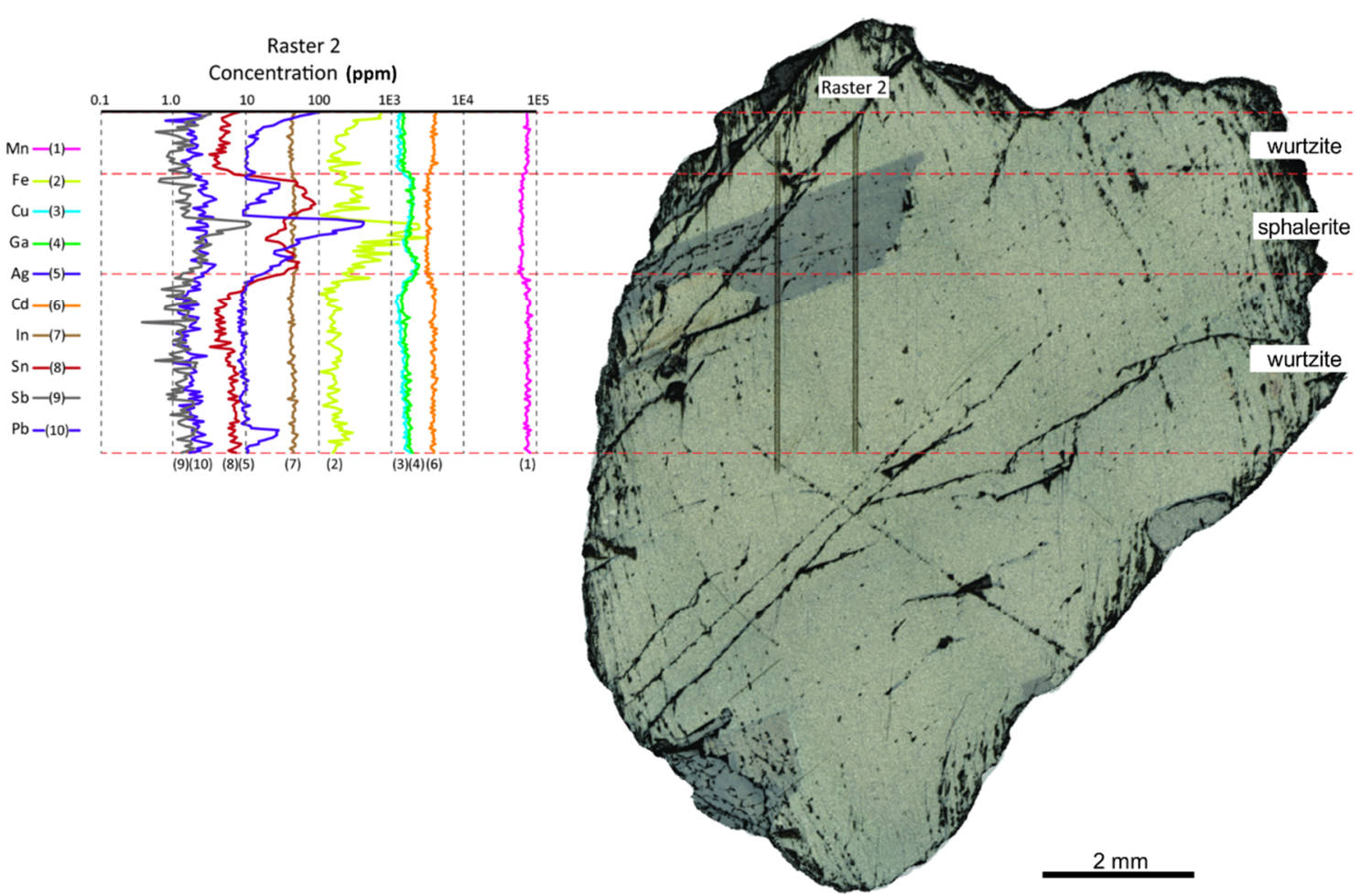

Figure 2. Photomicrograph of sample from Merelani Hills, Tanzania (G34171), taken in transmitted light under crossed nicols. The wurtzite- $4 \mathrm{H}$ regions, that make up most of the sample are pale dark green, while the epitaxially intergrown sphalerite is dark grey. The position of the two LA-ICP MS line scans are indicated. A log plot showing the variations in concentrations of minor and trace elements along Line scan 1 is superimposed.

\subsection{Powder X-Ray Diffraction}

The powder X-ray diffraction (XRD, Huber, Rimsting, Germany) patterns of the samples were collected from the offcut block after thin section preparation using a Huber Guinier Image Plate G670 with Co K $\alpha_{1}$ radiation $(\lambda=1.78892 \AA)$. The subsamples were ground under acetone in an agate mortar and spread on a Mylar film. Attempts were made to establish the proportions of sphalerite and wurtzite in samples by quantitative phase analysis (QPA), but it was found the QPA consistently underestimated the amount of wurtzite when compared to thin section examination. Cell dimensions were refined using Rietica [34].

\subsection{Electron Probe Microanalysis}

Major and minor element compositional data for the specimens were obtained using a Cameca SX51 electron microprobe (Cameca Gennevilliers Cedex, France) at Adelaide Microscopy, University of Adelaide. Analysis was undertaken using an accelerating potential of $20 \mathrm{kV}$ and a specimen current of $\sim 20 \mathrm{nA}$. A focused spot size was set at $<1 \mu \mathrm{m}$, however the effective resolution of the beam because of beam spread in the sample was of the order of $3 \mu \mathrm{m}$. Calibration was performed on certified natural and synthetic metal standards from Astimex and P\&H and Associates: natural pentlandite (Ni, $\mathrm{Fe}$ ), natural sphalerite $(\mathrm{Zn}, \mathrm{S})$, natural cobaltite $(\mathrm{Co})$, natural rhodonite $(\mathrm{Mn})$, natural chalcopyrite $(\mathrm{Cu})$, and $\mathrm{Cd}$ metal $(\mathrm{Cd})$. Data reduction was carried out in the SAMx software.

\subsection{LA-ICP-MS Analysis}

Trace and minor element concentrations for the two samples (Animas and Merelani) were analyzed using line scans with an Agilent 7700cx Series Quadrupole ICP-MS (Agilent Santa Clara, CA 95051, USA) coupled to an Applied Spectra M-50 laser ablation system at Adelaide Microscopy. The laser unit 
consists of a $193 \mathrm{~nm}$ ArF excimer laser and two volume cells designed by Laurin Technic Pty. Ablation was performed in a pure He atmosphere with a flow of $700 \mathrm{~mL} / \mathrm{min}$, and mixed with $\operatorname{Ar}(930 \mathrm{~mL} / \mathrm{min})$ immediately after the ablation cell. Prior to injection into the torch the mixture is passed through a pulse homogenizing device [35]. The ICP-MS (Inductively Coupled Plasma Mass Spectrometry) was optimized to maximize the sensitivity across the mass range, while keeping production of molecular oxide and doubly charged ion species as low as possible. Two line scans were performed on each specimen and located such that the raster lines crossed the wurtzite/sphalerite boundaries. The width of the line rasters are around $50 \mu \mathrm{m}$. Immediately prior to, and after sample line scans, identical scans, were conducted for calibration, on the USGS certified standard MASS-1, comprising a pressed pellet of precipitated $\mathrm{Cu}-\mathrm{Fe}-\mathrm{Zn}$ sulfide standard [36]. Data were subsequently corrected using Excel by carrying out background subtracted, mass-bias and drift correction, and finally converted to concentrations $(\mathrm{ppm})$ as a function of distance utilizing the measured $\mathrm{Zn}$ concentration from probe analysis for the internal standard normalization. Measured isotopes consisted of: ${ }^{55} \mathrm{Mn},{ }^{57} \mathrm{Fe},{ }^{59} \mathrm{Co},{ }^{60} \mathrm{Ni},{ }^{65} \mathrm{Cu},{ }^{66} \mathrm{Zn}$, ${ }^{71} \mathrm{Ga},{ }^{75} \mathrm{As},{ }^{77} \mathrm{Se},{ }^{95} \mathrm{Mo},{ }^{107} \mathrm{Ag},{ }^{111} \mathrm{Cd},{ }^{115} \mathrm{In},{ }^{118} \mathrm{Sn},{ }^{121} \mathrm{Sb},{ }^{197} \mathrm{Au},{ }^{202} \mathrm{Hg},{ }^{205} \mathrm{Tl},{ }^{208} \mathrm{~Pb}$ and ${ }^{209} \mathrm{Bi}$, with dwell times ranging from $10 \mathrm{~ms}$ for both $\mathrm{Zn}$ and $\mathrm{S}$, and $50 \mathrm{~ms}$ for the remaining masses. Despite Ge being an important element in sphalerite/wurtzite, the MASS-1 standard does not contain this element and thus could not be quantified in this study. Because of its low level and inhomogeneity of Mn (280 \pm 80 ppm), the MASS-1 standard is unsuitable for accurate Mn analysis and values from the electron microprobe data are considered much more reliable for high Mn samples such as Merelani. The full data for the raster line scans are available in Table S1

LA-ICP-MS (laser ablation inductively coupled plasma mass spectrometry) mapping was conducted at a repetition rate of $10 \mathrm{~Hz}, 64 \mu \mathrm{m}$ spot size, and output fluence of $\sim 2.5 \mathrm{Jcm}^{-2}$. A $30 \mathrm{~s}$ background acquisition was acquired at the start of every raster. Dwell times for all elements were set to $7 \mathrm{~ms}$ to optimize response time of the mass spectrometer at the expense of detection limit. Identical rasters were carried out on the MASS-1 standard at the beginning and end of the mapping run.

Elemental images were compiled and processed using the program Iolite developed by the Melbourne Isotope Group at Melbourne University [37,38]. Processing of the map involves background subtraction and drift modelling and correction before conversion into 2D elemental intensity images.

\section{Results}

Powder X-ray diffraction conducted on samples taken from various points across the off cut block of the Animas specimen, indicates that sphalerite forms overgrowths on pyrite at the base of the sample, and that the upper surface is predominantly wurtzite-2H but nevertheless contains varying amounts of sphalerite. Several different sub-samples were analyzed from the upper part of this specimen, but none gave a pure wurtzite X-ray diffraction pattern. This contrasts with optical images of thin sections under crossed nicols that highlight the optical anisotropy of the wurtzite compared with the isotropic nature of sphalerite. Optical imaging indicates that apart from the base of the sample, wurtzite is dominant and sphalerite occurs as narrow bands or as patches near the upper surface (Figure 1). The cell parameters for the Animas wurztite-2H and sphalerite are $a=3.8316(3) c=6.2354(2)$ $\AA$ and $a=5.4128(1) \AA$, respectively, and these values are in good agreement with those predicted in the literature $[39,40]$.

Powder X-ray diffraction analysis shows that the wurtzite from Merelani is the wurtzite- $4 \mathrm{H}$ polytype with cell parameters $a=3.8504(2), c=12.5804(7) \AA$ and the sphalerite component has $a=5.4482(3) \AA$. The wurtzite- $4 \mathrm{H} a$ parameter is in good agreement with that predicted for a Mn-rich wurtzite [18], however the $c / 2$ is slightly shorter than predicted for a Mn-rich wurztite-2H of the appropriate composition. This difference is likely related to the $4 \mathrm{H}$ stacking. Taken with crossed nicols, the optical image of the Merelani sample (Figure 2), shows that most of sample is wurtzite-4H with a sharp band of epitaxial sphalerite running across the center of the sample.

Major and minor element compositional data for the Animas and Merelani samples are summarized in Table 1. There are significant difference between the chemistries of the two samples at the minor 
element level, particularly for Fe and Mn. The mean Fe content for the Animas wurtzite is $4.9 \mathrm{wt} \%$ and that for the sphalerite is $2.3 \mathrm{wt} \%$, based on a phase assignment by mineral optics. The wurtzite and sphalerite from Merelani have only trace levels of Fe (200 to 500 ppm).

Table 1. Summary of compositional and crystallographic information on epitaxial intergrowths of wurtzite and sphalerite. (ulq) is upper limit of accurate quantification, (bld) below level of detection, (e.s.d) estimated standard deviations.

\begin{tabular}{|c|c|c|c|c|}
\hline & \multicolumn{2}{|c|}{ Animas-Chocaya Mine G33739 } & \multicolumn{2}{|c|}{ Merelani G34171 } \\
\hline & Wurtzite & Sphalerite & Wurztite & Sphalerite \\
\hline Unit Cell & $\begin{array}{c}a=3.8136(1) \\
c=6.2354(2) \AA\end{array}$ & $a=5.4128(1) \AA$ & $\begin{array}{c}a=3.8504(2) \\
c=12.5804(7) \AA\end{array}$ & $a=5.4482(3) \AA$ \\
\hline Element & $w t \%$ & $\mathrm{w} \%$ & $w t \%$ & $w t \%$ \\
\hline Points & (23) & (28) & $(40)$ & (11) \\
\hline $\mathrm{S}$ & 32.9 & 32.9 & 33 & 32.8 \\
\hline (range) & $(32.3-33.9)$ & $(31.4-33.3)$ & $(32.7-33.4)$ & $(32.7-33.1)$ \\
\hline $\mathrm{Fe}$ & $\begin{array}{c}4.9 \\
(2.7-6.3)\end{array}$ & $\begin{array}{c}2.3 \\
(1.6-2.7)\end{array}$ & bld & bld \\
\hline Mn & bd & bld & $\begin{array}{c}9.1 \\
(8.2-9.4)\end{array}$ & $\begin{array}{c}7.9 \\
(7.7-8.2)\end{array}$ \\
\hline $\mathrm{Cu}$ & $\begin{array}{c}0.1 \\
\text { (bld-0.2) }\end{array}$ & $\begin{array}{c}0.1 \\
(0.0-0.2)\end{array}$ & $\begin{array}{c}0.1 \\
(0.0-0.4)\end{array}$ & $\begin{array}{c}0.3 \\
(0.3-0.4)\end{array}$ \\
\hline $\mathrm{Zn}$ & $\begin{array}{c}59.9 \\
(57.7-62.6)\end{array}$ & $\begin{array}{c}63.3 \\
(62.9-64.3)\end{array}$ & $\begin{array}{c}55.5 \\
(54.8-56.2)\end{array}$ & $\begin{array}{c}56.5 \\
(56.2-57.0)\end{array}$ \\
\hline $\mathrm{Cd}$ & $\begin{array}{c}0.9 \\
(0.5-1.3)\end{array}$ & $\begin{array}{c}0.7 \\
(0.5-1.0)\end{array}$ & $\begin{array}{c}0.4 \\
(0.2-0.5)\end{array}$ & $\begin{array}{c}0.4 \\
(0.3-0.5)\end{array}$ \\
\hline $\mathrm{Pb}$ & & & $\begin{array}{c}0.1 \\
\text { (bld-0.4) }\end{array}$ & $\begin{array}{c}0.1 \\
\text { (bld-0.2) }\end{array}$ \\
\hline Total & 98.7 & 99.3 & 98.2 & 98.1 \\
\hline \multicolumn{5}{|c|}{ Trace Elements (ppm) } \\
\hline $\begin{array}{l}\text { Mn } \\
\text { (e.s.d) }\end{array}$ & $\begin{array}{l}40 \\
(5)\end{array}$ & $\begin{array}{l}25 \\
\text { (1) }\end{array}$ & & \\
\hline $\mathrm{Fe}$ & $\begin{array}{l}\text { >ulq } \\
(1700)\end{array}$ & $\begin{array}{l}\text { >ulq } \\
(1300)\end{array}$ & $\begin{array}{l}210 \\
(30)\end{array}$ & $\begin{array}{c}530 \\
(170)\end{array}$ \\
\hline Co & $\begin{array}{c}0 \\
(0)\end{array}$ & $\begin{array}{c}0 \\
(0)\end{array}$ & $\begin{array}{l}1 \\
(0)\end{array}$ & $\begin{array}{c}0 \\
(0)\end{array}$ \\
\hline $\mathrm{Cu}$ & $\begin{array}{l}850 \\
(90)\end{array}$ & $\begin{array}{l}3200 \\
(420)\end{array}$ & $\begin{array}{l}1300 \\
(30)\end{array}$ & $\begin{array}{l}1900 \\
(80)\end{array}$ \\
\hline $\mathrm{Ga}$ & $\begin{array}{l}400 \\
(40)\end{array}$ & $\begin{array}{l}400 \\
(40)\end{array}$ & $\begin{array}{l}1450 \\
(30)\end{array}$ & $\begin{array}{l}1750 \\
(80)\end{array}$ \\
\hline As & $\begin{array}{c}1 \\
(0)\end{array}$ & $\begin{array}{c}2 \\
(1)\end{array}$ & $\begin{array}{l}3 \\
(1)\end{array}$ & $\begin{array}{l}11 \\
(5)\end{array}$ \\
\hline Se & $\begin{array}{c}0 \\
(0)\end{array}$ & $\begin{array}{c}0 \\
(1)\end{array}$ & $\begin{array}{l}1500 \\
(25)\end{array}$ & $\begin{array}{l}1500 \\
(25)\end{array}$ \\
\hline $\mathrm{Ag}$ & $\begin{array}{l}1400 \\
(130)\end{array}$ & $\begin{array}{l}1500 \\
(300)\end{array}$ & $\begin{array}{c}2 \\
(0)\end{array}$ & $\begin{array}{c}2 \\
(0)\end{array}$ \\
\hline $\mathrm{Cd}$ & $\begin{array}{l}7500 \\
(360)\end{array}$ & $\begin{array}{l}8600 \\
(570)\end{array}$ & $\begin{array}{c}3600 \\
(60)\end{array}$ & $\begin{array}{c}53000 \\
(70)\end{array}$ \\
\hline In & $\begin{array}{l}150 \\
(30)\end{array}$ & $\begin{array}{c}600 \\
(170)\end{array}$ & $\begin{array}{l}40 \\
(1)\end{array}$ & $\begin{array}{l}40 \\
(1)\end{array}$ \\
\hline Sn & $\begin{array}{l}1100 \\
(110)\end{array}$ & $\begin{array}{l}2700 \\
400)\end{array}$ & $\begin{array}{c}5 \\
(0)\end{array}$ & $\begin{array}{l}33 \\
(5)\end{array}$ \\
\hline $\mathbf{S b}$ & $\begin{array}{l}30 \\
(6)\end{array}$ & $\begin{array}{l}170 \\
(40)\end{array}$ & $\begin{array}{c}1 \\
(0)\end{array}$ & $\begin{array}{c}2 \\
(0)\end{array}$ \\
\hline $\mathrm{Hg}$ & $\begin{array}{c}0 \\
(0)\end{array}$ & $\begin{array}{c}0 \\
(0)\end{array}$ & $\begin{array}{c}2 \\
(0)\end{array}$ & $\begin{array}{c}2 \\
(0)\end{array}$ \\
\hline $\mathrm{Tl}$ & $\begin{array}{c}0 \\
(0)\end{array}$ & $\begin{array}{c}0 \\
(0)\end{array}$ & $\begin{array}{c}0 \\
(0)\end{array}$ & $\begin{array}{c}1 \\
(0)\end{array}$ \\
\hline $\mathbf{P b}$ & $\begin{array}{c}70 \\
(10)\end{array}$ & $\begin{array}{c}70 \\
(10)\end{array}$ & $\begin{array}{l}20 \\
(5)\end{array}$ & $\begin{array}{c}40 \\
(10)\end{array}$ \\
\hline
\end{tabular}

The sample from Merelani shows that the mean Mn content of the sphalerite regions of the crystal to be $\sim 14 \mathrm{~mol} \%(7.9 \mathrm{wt} \%)$, and the wurtzite regions $\sim 16 \mathrm{~mol} \%(9.1 \mathrm{wt} \%)$. It has been reported that $\mathrm{Mn}$ levels of $\geq 8 \mathrm{~mol} \%$ stabilizes wurtzite over sphalerite [18] but the Merelani material indicates that the stability range of the sphalerite structure is extended to more Mn-rich compositions in that deposit. The extension of the sphalerite compositional field towards MnS could also be influenced by the effects 
of other minor and trace element substitutions, together with the PT conditions and variation in $f S_{2}$ during growth. The wurtzite and sphalerite from Animas are essentially Mn-free.

The contents of the other minor elements $\mathrm{Cd}$ and $\mathrm{Cu}$ are less variable; for the Animas sample the sphalerite and wurtzite areas have mean Cd concentration of 8597(568) ppm and 7645(358) ppm, and mean $\mathrm{Cu}$ concentrations of 3161(419) ppm and 844(90) ppm, respectively (see Table 1). Estimated standard deviation (e.s.d.) values, calculated from the individual elemental values from LA-ICP line scans, are given in brackets. For the Merelani sample, the mean $\mathrm{Cu}$ value for wurtzite is 1267(26) ppm and that for the sphalerite region 1932(80) ppm. The mean Cd values for the Merelani wurtzite is 3582(60) ppm and for the sphalerite it is 2982(67) ppm. Thus, the difference in Cd levels between the wurtzite and sphalerite at these two localities are very small, given the estimated standard deviations associated with the analyses given above and in Table 1, but the $\mathrm{Cu}$ concentration in wurtzite from Animas are significantly lower than in co-existing sphalerite.

Variation in minor and trace element compositions in the Animas sample is visualized in the LA-ICP-MS maps (Figure 3), and transverse data of represented by LA-ICP-MS raster scans (Figure 4). It is clear from the LA-ICP-MS raster traverse and the series of element maps that the concentrations of the various minor and trace elements vary widely and frequently across the sample, and to a significant extent, mirror the growth banding. LA-ICP-MS element mapping is able to resolve 10s of micron-scale banding but it is reasonable to assume based on published data (e.g., [21]) that this may continue to the scale of nanometers. The four sphalerite bands coincide with increases in the local concentrations of In, $\mathrm{Sn}$, and Ag (Figure 4). Copper also shows a similar trend, but also shows an overall increase from the base of the sample (interfaced by the pyrite crystal) to the top. Variation in other elements, such as $\mathrm{Cd}, \mathrm{Fe}$, and $\mathrm{Ga}$, does not correlate strongly with the sphalerite banding. The elements maps serve to highlight the variation in minor and trace elements during hydrothermal growth and switching between crystallization of either wurtzite or sphalerite.
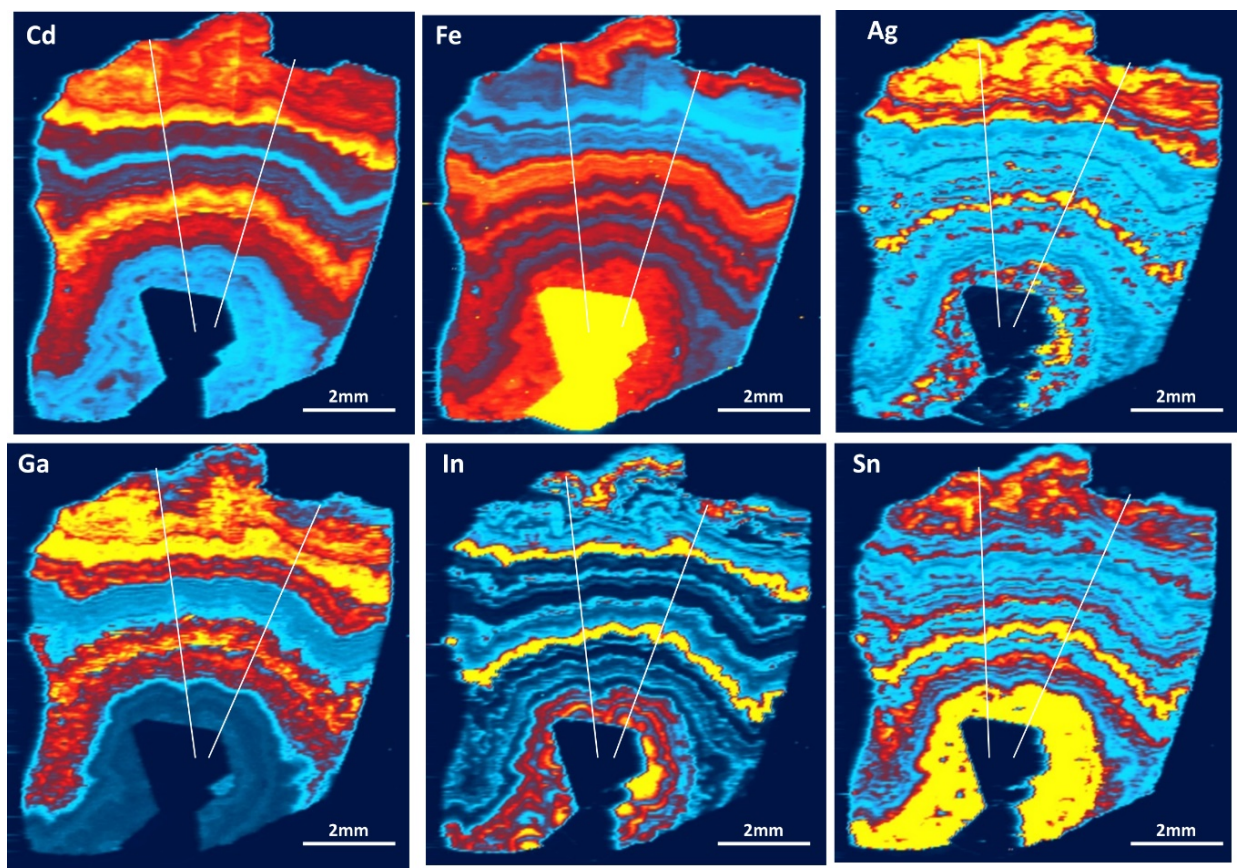

Figure 3. LA-ICP-MS element maps for $\mathrm{Cd}, \mathrm{Fe}, \mathrm{Ag}, \mathrm{Ga}$, In and $\mathrm{Sn}$ from a cross-section of the wurtzite-sphalerite intergrowth (SAM G33739). The coloring is based on relative concentrations on a linear scale, with red being highest, yellow intermediate concentrations, and blue lowest, clearly showing trace element variation with growth zoning. The positions of the line scan 1 (right-hand line) and line scan 2 (left-hand line) scans are indicated by the white lines. 


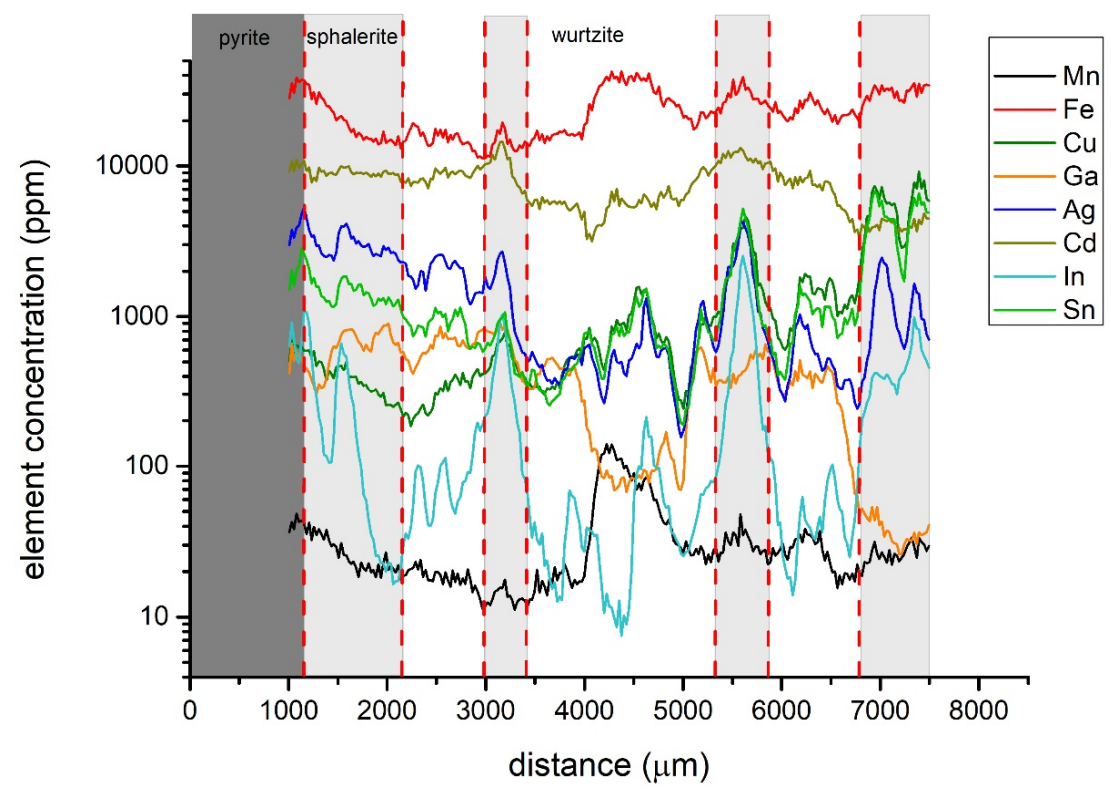

Figure 4. Laser ablation inductively coupled plasma mass spectrometry (LA-ICP-MS) concentration plot for selected minor and trace elements of the Animas sample. The position of the sphalerite bands are indicate by pale grey shading, the remaining are, other than the pyrite at the base, is wurtzite (assignment on the basis of mineral optics). Note the log scale for concentration.

\section{Discussion}

Thus, in both samples there are clear chemical changes associated with the switch in polytype, but the nature of these changes is different in each case. The change in Mn concentration in the Merelani material is in broad agreement with the phase studies [18], although the Mn content of the sphalerite is considerably higher than predicted from their phase studies.

Johan [41] proposed a series of coupled substitutions to explain the trace and minor element substitution in sphalerite. Such substitutions include $\mathrm{Cu}^{+}+\mathrm{Ga}^{3+} \leftrightarrow 2 \mathrm{Zn}^{2+}, \mathrm{Cu}^{+}+\mathrm{In}^{3+} \leftrightarrow 2 \mathrm{Zn}^{2+}$, or $2 \mathrm{Ag}^{+}+\mathrm{Sn}^{4+} \leftrightarrow 3 \mathrm{Zn}^{2+}$; many others have been explored by various authors $([20,26,41,42]$ and others). The LA-ICP-MS raster traverses show the local variation in minor and trace elements across the samples. This is more evident in the Animas sample, which shows well developed rhythmic growth zoning that sometimes involves switching between the wurtzite and the sphalerite polytypes. The Merelani sample does not show obvious growth zoning, as it is part of one crystal lath of sphalerite within homogeneous wurtzite (Figure 5).

Plotting the variation in trace and minor elements across the grains allows one to examine the spatial nature of possible coupled substitutions. For example, the coupled substitution $2 \mathrm{Ag}^{+}+\mathrm{Sn}^{4+} \leftrightarrow$ $3 \mathrm{Zn}^{2+}$ in the Animas sample (Figure 6a). The levels of both Ag and Sn vary across the section from around $500 \mathrm{ppm}$ to above $4000 \mathrm{ppm}$ for Ag, and to over $6000 \mathrm{ppm}$ for Sn. The degree of coupling between the concentrations of $\mathrm{Ag}$ and $\mathrm{Sn}$ also varies across the sample. The ratio of Ag to Sn closely approximates 2:1, for the first $1 \mathrm{~mm}$ of the $\mathrm{ZnS}$ overgrowing pyrite. The levels of $\mathrm{Ag}$ and $\mathrm{Sn}$ are enriched in the sphalerite regions compared to the wurtzite areas (Figure 6a). The coupling ratio appears, however, to break down in the outer growth zones, when the ratio of Ag to Sn approximates 1:1 and toward the outer surface the concentration of Sn becomes dominant over that of Ag. If the change in composition along the traverse is replotted with the concentration of $\mathrm{Cu}$ added to that of $\mathrm{Ag}$, such that the substitution now becomes $2(\mathrm{Ag}+\mathrm{Cu})+\mathrm{Sn} \leftrightarrow 3 \mathrm{Zn}$, then the ratio is approximately 2:1 along the length of the traverse (Figure $6 \mathrm{~b}$ ). The local variations in concentrations persist and the sphalerite regions are enriched in $\mathrm{Ag}, \mathrm{Cu}$ and $\mathrm{Sn}$ compared to the wurtzite regions. This substitution is not observed in the Merelani sample, as the Ag levels are $<5 \mathrm{ppm}$ across the sample while the Sn levels are low in the wurtzite region ( $\sim 5 \mathrm{ppm})$ and range up to $70 \mathrm{ppm}$ in the sphalerite region (Figure $5 \mathrm{c}$ ). 


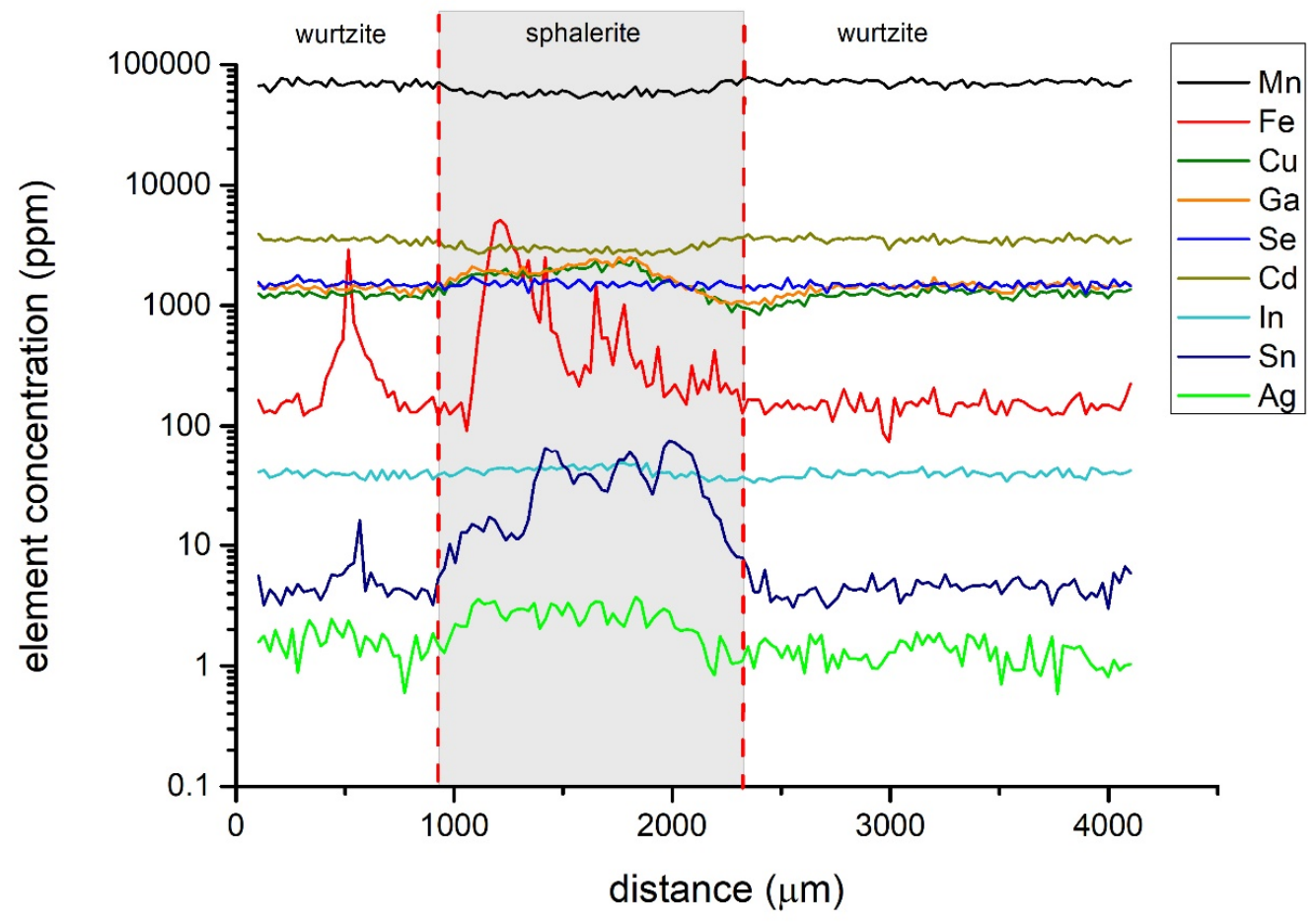

(a)

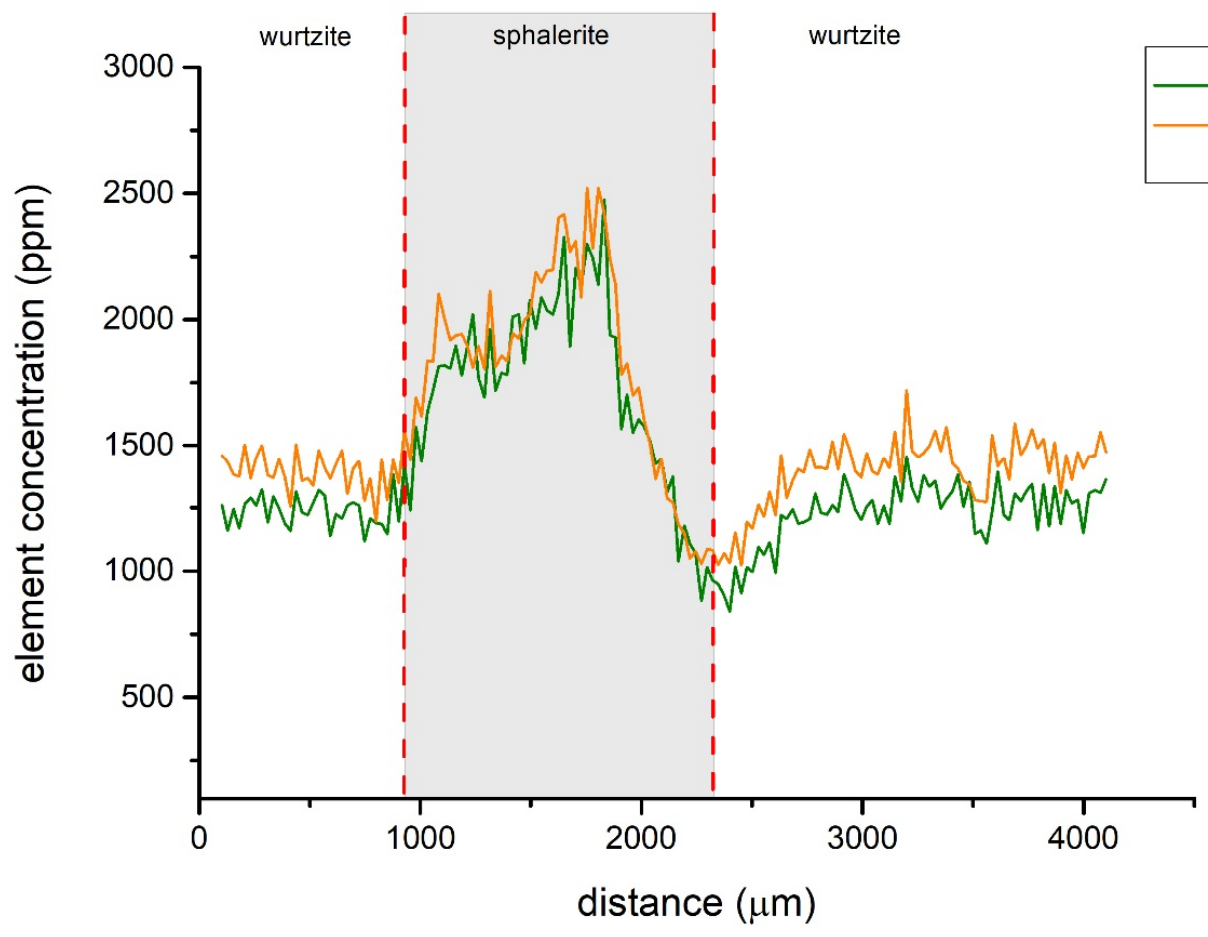

(b)

Figure 5. Cont. 


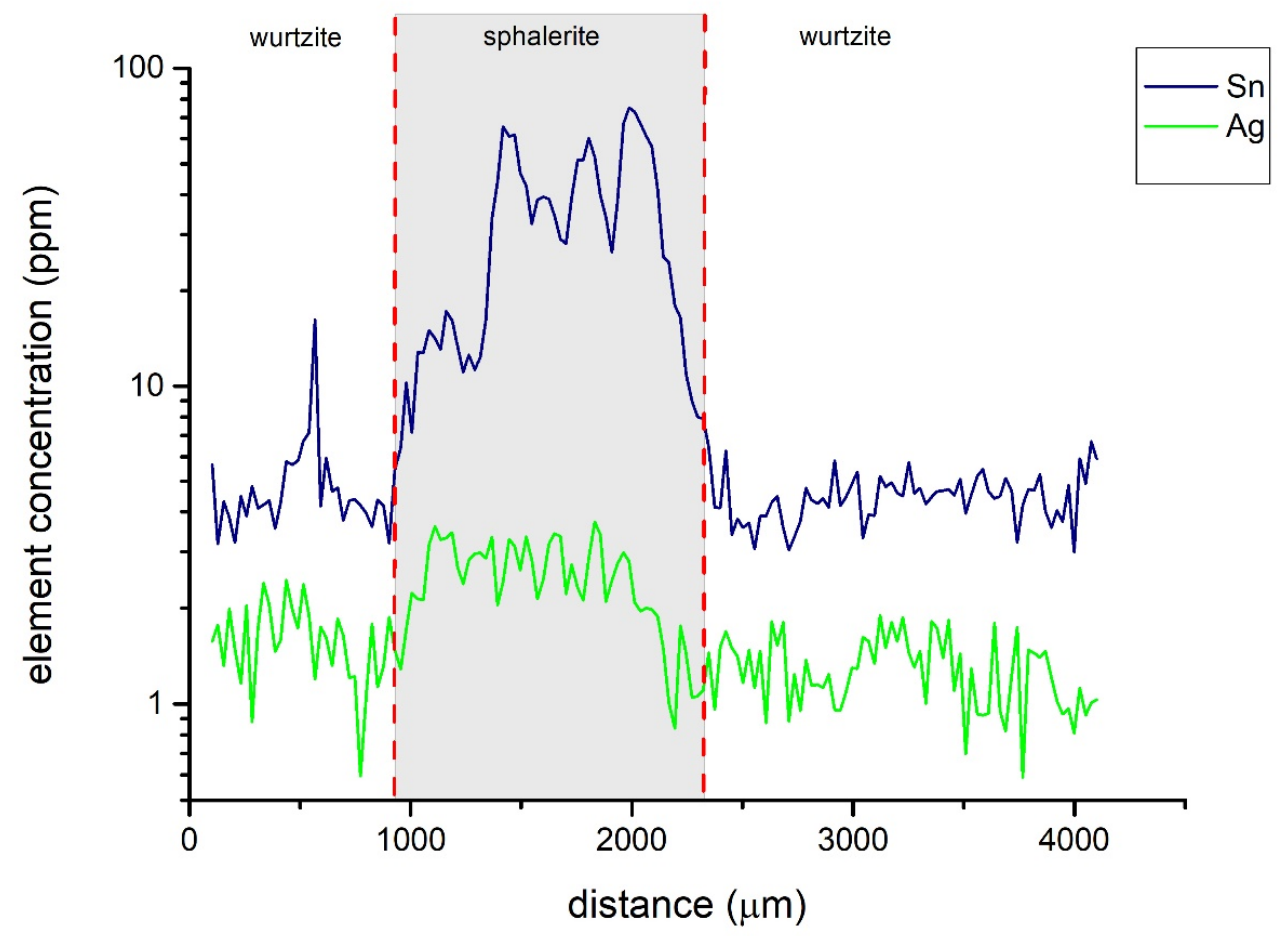

(c)

Figure 5. LA-ICP-MS line scans showing the distribution of minor and trace elements between the wurtzite and sphalerite regions of the Merelani sample. (a) Plot of minor and trace elements along Line scan 1. (b) Plot showing the coupling between $\mathrm{Cu}$ and $\mathrm{Ga}$ in the Merelani sample. (c) Plot showing the lack of coupling between the concentrations of Sn and Ag in the Merelani sample. Note that trace element levels are elevated in the sphalerite region.

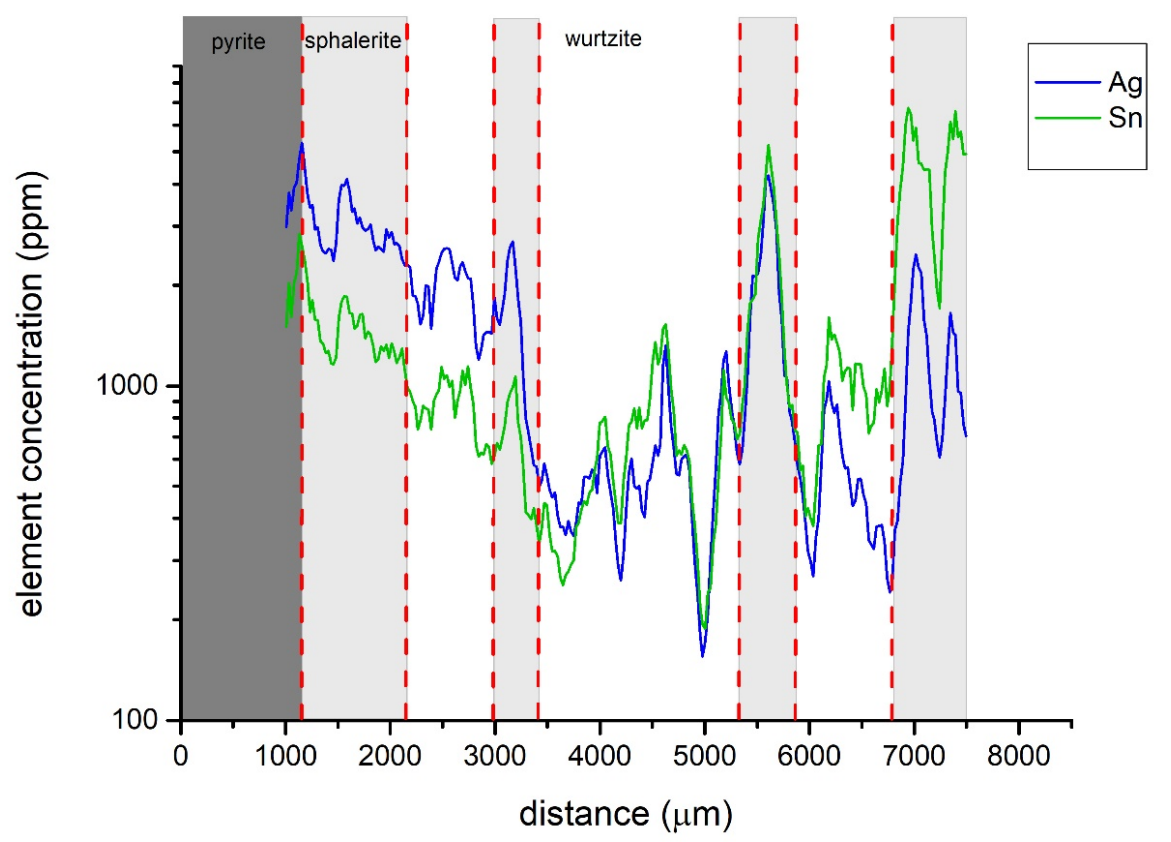

(a)

Figure 6. Cont. 


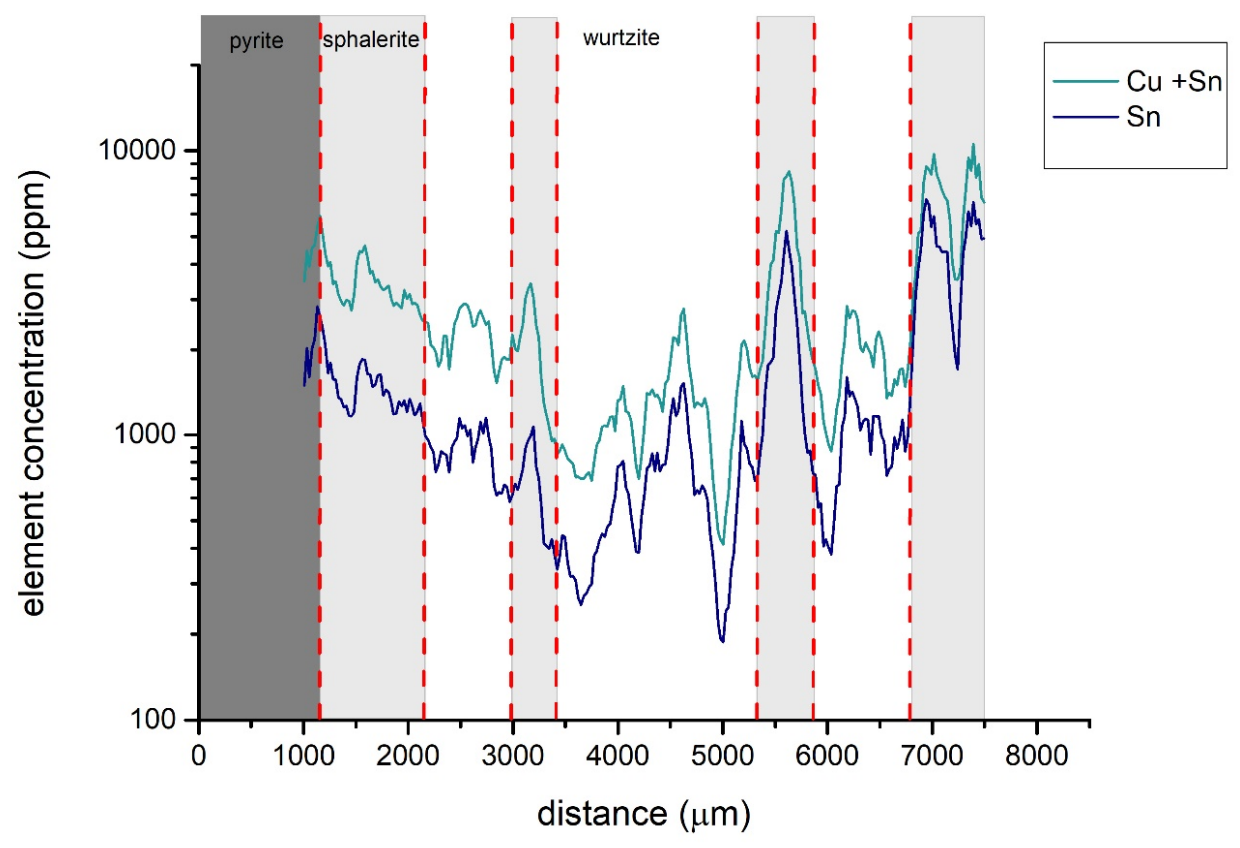

(b)

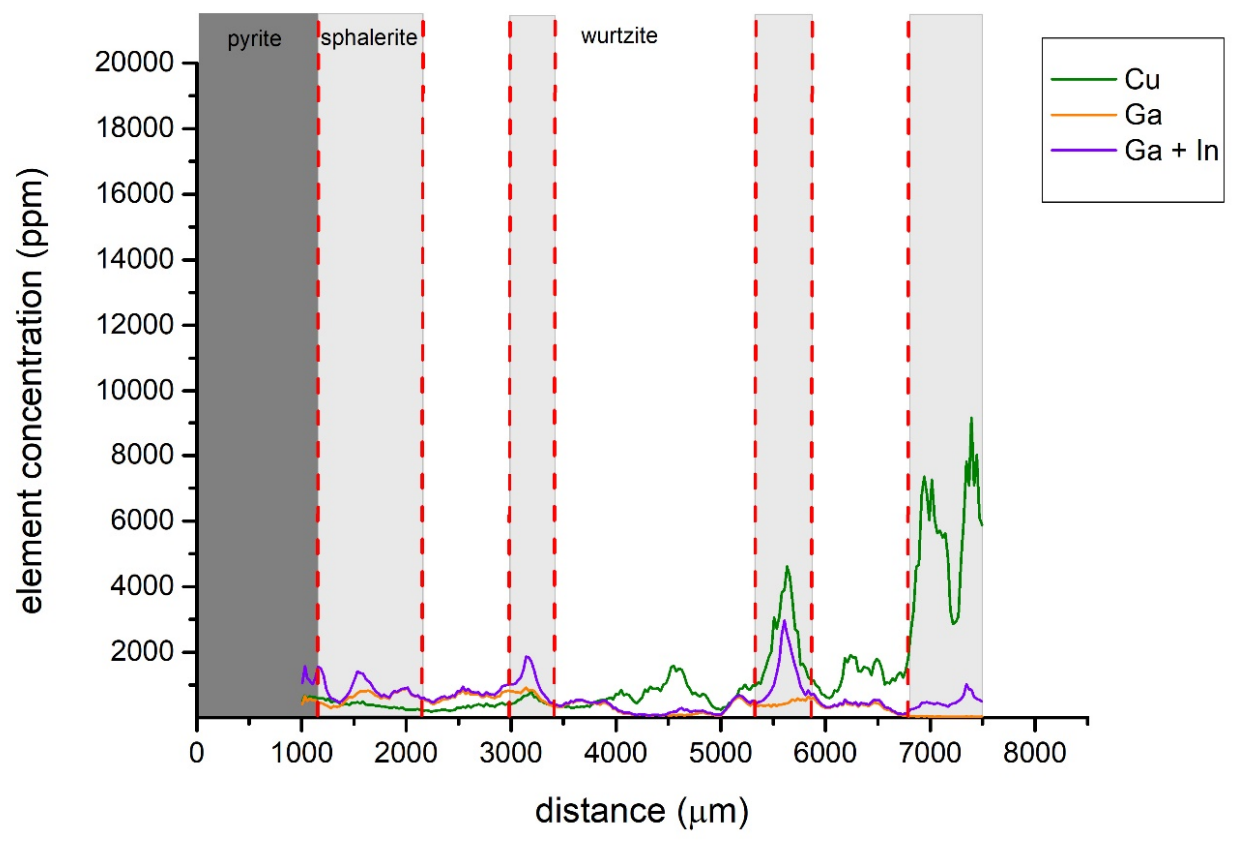

(c)

Figure 6. LA-ICP-MS traverses across Animas wurtzite-sphalerite sample. (a) traverse showing the partial coupling of the $2 \mathrm{Ag}^{+}+\mathrm{Sn}^{4+} \leftrightarrow 3 \mathrm{Zn}^{2+}$ substitution, which breaks down about $4000 \mu \mathrm{m}$ from the bottom (pyrite) of the sample. (b) The traverse showing the $2(\mathrm{Ag}+\mathrm{Cu})+\mathrm{Sn} \leftrightarrow 3 \mathrm{Zn}$ substitution across the sample. (c) traverse showing the lack of coupling between $\mathrm{Cu}$, and $\mathrm{Ga}$ or $\mathrm{Cu}$ and $\mathrm{Ga}+\mathrm{In}$.

A well-documented coupled substitution in $\mathrm{ZnS}$ is the $\mathrm{Cu}^{+}+\mathrm{Ga}^{3+} \leftrightarrow 2 \mathrm{Zn}^{2+}$ substitution. This is observed in the Merelani sample across both the wurtzite and sphalerite regions (Figure $5 b$ ). The $\mathrm{Cu}$ and Ga levels are around 1200 ppm in the wurtzite region and increase to over $1800 \mathrm{ppm}$ in the sphalerite zone. This coupled substitution does not, however, hold in the Animas sample. In the inner 
zone of this sample, within $2 \mathrm{~mm}$ of the pyrite core, the coupled substitution is only very approximately observed, but with Ga generally dominant. Further from the base of the zinc sulfide banding $\mathrm{Cu}$ dominates. A plot of $\mathrm{Cu}+(\mathrm{Ga}+\mathrm{In})$ does not show a coupled substitution either (Figure $6 \mathrm{c})$. In this case the trace element profile is dominated by the $2(\mathrm{Ag}+\mathrm{Cu})+\mathrm{Sn}$ substitution and the increase in the levels of the substitution correlate with the sphalerite bands. Note that the minerals pirquitasite $\left(\mathrm{Ag}_{2} \mathrm{ZnSnS}_{4}\right)$, kësterite $\left(\mathrm{Cu}_{2} \mathrm{ZnSnS}{ }_{4}\right)$ and hocartite $\left(\mathrm{Cu}_{2} \mathrm{FeSnS}_{4}\right)$ represent "end-members" of this coupled substitution and all have structures related to ordered sphalerite derivatives [43], however our sample appears to be free of inclusions of these minerals or of other phases, notably roquesite $\left(\mathrm{CuInS}_{2}\right)$ or laforêtite $\left(\mathrm{AgInS}_{2}\right)$, at least at the microscopic scale.

The LA-ICP-MS traverses show that there are clear differences in chemistry between co-existing sphalerite and wurtzite at the minor and trace element levels. The levels of non-divalent trace elements $(\mathrm{Ag}, \mathrm{Cu}, \mathrm{Ga}, \mathrm{In}, \mathrm{Sn})$ are higher in sphalerite compared to the coexisting wurtzite, but there is no unequivocal crystal chemical link for the switch between polytypes based on the available data. There is also no way to experimentally determine the sulfur stoichiometry in these samples to a sufficient level of analytical accuracy to unequivocally establish a direct link between non-stoichiometry, the stability of sphalerite (cation deficient) and wurtzite (sulfur deficient), as reported previously [16]. O'Keeffe and Hyde [19] concluded that the wurtzite form was favored by cation-cation interactions and thus should be more stable when sulfur deficient. From this, a reasonable hypothesis might be that substitution of impurity ions, particularly those with tri- or tetravalent charge, into the structure would introduce strain that is more easily accommodated by the $3+1$ tetrahedral coordination of the wurtzite structure, where the apical M-S distance is not constrained by symmetry, thus allowing the large cations to be more readily accommodated (see [44]). However, the current study is not consistent with this hypothesis, as the sphalerite component of both samples studied here clearly contains the higher concentrations of trivalent and tetravalent ions. In an autocorrelation infrared spectroscopy study of Fe-rich sphalerite, Pring et al. [45] determined considered little strain is introduced into the structure by minor element substitutions of Fe. The stabilization of one polytype over the other is reflected in composition, as shown by the enrichment of trace elements in sphalerite over co-existing wurtzite, and to sulfur stoichiometry as reported previously [16]. This is, however, ultimately linked to changes in the hydrothermal fluid conditions during crystallization and the departure from an M:S ratio of 1:1. The trace element endowment of sphalerite also appears influenced by the presence/absence and abundance of other co-existing minerals, into which individual trace elements may prefer to substitute [46].

Supplementary Materials: The following are available online at http://www.mdpi.com/2075-163X/10/2/147/s1, Table S1: Trace element values for the two raster scans on each of the Merelani and the Animas samples.

Author Contributions: Conceptualization: A.P., C.E.L., and N.J.C. Methodology: C.E.L., B.W., A.M., and A.P.; Formal analysis: B.W., A.M. Writing—original draft preparation: A.P. Writing-review and editing: N.J.C. and C.E.L. Visualization: B.W. and C.E.L. All authors have read and agreed to the published version of the manuscript.

Funding: We acknowledge the financial support of the Australian Research Council's Discovery scheme grants DP077229 and DP1095069

Acknowledgments: We acknowledge the financial support of the Australian Research Council's Discovery scheme. We thank Catlin Couzner for her extensive initial study of the trace element chemistry of wurtzite, which proved that it is not possible to establish the differences in trace and minor element chemistry of wurtzite, without analyzing wurtzite-sphalerite intergrowths down to the nanoscale. We also thank Nicole Allen and Christine Ta for assistance with some of the analysis in the early stages of this study. We gratefully acknowledge the gift of samples of Tanzanian wurtzite/sphalerite by Mike Keim of Marin Minerals and John Jaszczak. Allan Pring thanks the Master and Fellows of Magdalene College, Cambridge for a visiting fellowship.

Conflicts of Interest: The authors declare no conflict of interest.

\section{References}

1. Evans, H.T.; McKnight, E.T. New wurtzite polytypes from Joplin Missouri. Am. Mineral. 1959, 44, $1210-1218$.

2. Ramdohr, P. The Ore Minerals and Their Intergrowths, 3rd ed.; Pergamon Press: Oxford, UK, 1969; p. 1174. 
3. Vaughan, D.J.; Craig, J.R. Mineral Chemistry of Metal Sulfides; Cambridge University Press: Cambridge, UK, 1978; p. 493.

4. Makeev, A.B.; Tauson, V.L. On the possible genesis of several ZnS polytypes (by data of study of Pai-Khoi sphalerites). In Crystal Chemistry and Structural Mineralogy; Frank-Kamenetsky, V.A., Ed.; Nauka: Moscow, Russia, 1979; pp. 18-25. (In Russian)

5. Tauson, V.L.; Abramovich, M.G.; Akimov, V.V.; Scherbakov, V.A. Thermodynamics of real mineral crystals: Equilibrium crystal shape and phase size effect. Geochim. Cosmochim. Acta 1993, 57, 815-822. [CrossRef]

6. Chaplygin, I.V.; Mozgova, N.N.; Mokhov, A.V.; Koporulia, E.V.; Bernhart, H.J.; Bryzgalov, I.A. Minerals of the system ZnS-CdS from fumaroles of the Kudriay volcano, Iturup Island, Kuriles, Russia. Can. Mineral. 2007, 45, 709-722. [CrossRef]

7. Allen, E.T.; Crenshaw, J.L. The sulfides of zinc, cadmium and mercury; their crystalline forms and genetic conditions. Am. J. Sci. Ser. 1912, 34, 341-396. [CrossRef]

8. Kremheller, A. Zinc sulfide single crystals for phosphor research. Sylvania Technol. 1955, 8, 11-15.

9. Addamiano, A.; Aven, M. Some properties of zinc sulfide crystals grown from melt. J. Appl. Phys. 1960, 31, 36-39. [CrossRef]

10. Samelson, H. Vapor phase growth and properties of zinc sulfide single crystals. J. Appl. Phys. 1961, 32, 309-317. [CrossRef]

11. Samelson, H. Growth of cubic ZnS single crystals by chemical transport processes. J. Appl. Phys. 1962, 33, 1779-1783. [CrossRef]

12. Kullerud, G. The FeS-ZnS system. A geologic thermometer. Norsk Geol. Tidsskr. 1953, 32, 61-147.

13. Buerger, M.J. The pyrite-marcasite relation. Am. Mineral. 1934, 19, 37-61.

14. Barton, P.B., Jr.; Toulmin, P., III. Phase relations involving sphalerite in the Fe-Zn-S system. Econ. Geol. 1966, 61, 815-849. [CrossRef]

15. Pankratz, L.B.; King, E.G. High-Temperature Heat Contents and Entropies of Two Zinc Sulfides and Four Solid Solutions of Zinc and Iron Sulfides, Bureau of Mines. Rep. Investig. 1965, 1965, 6708.

16. Scott, S.D.; Barnes, H.L. Sphalerite-wurtzite equilibria and stoichiometry. Geochim. Cosmochim. Acta 1972, 36, 1275-1295. [CrossRef]

17. Lepetit, P.; Bente, K.; Doering, T.; Luckhaus, S. Crystal chemistry of Fe-containing sphalerites. Phys. Chem. Miner. 2003, 30, 185-191. [CrossRef]

18. Knitter, S.; Binnewies, M. Chemical vapor transport of solid solutions. 5 Chemical vapor transport of $\mathrm{MnS} / \mathrm{ZnS}, \mathrm{FeS} / \mathrm{ZnS}$ and FeS/MnS mixed crystals. Z. Anorgan. Allgem. Chem. 1999, 625, 1582-1588. [CrossRef]

19. O'Keeffe, A.; Hyde, B.G. Non-bonded Interaction and the Crystal chemistry of tetrahedral structures related to the Wurtzite type (B4). Acta Cryst. 1978, B34, 3519-3528. [CrossRef]

20. Cook, N.J.; Ciobanu, C.L.; Pring, A.; Skinner, W.; Shimizu, M.; Danyushevsky, L.; Saini-Eidukat, B.; Melcher, F. Trace and minor elements in sphalerite: A LA-ICPMS study. Geochim. Cosmochim. Acta 2009, 73, 4761-4791. [CrossRef]

21. Cook, N.J.; Ciobanu, C.L.; Brugger, J.; Etschmann, B.; Howard, D.L.; de Jonge, M.D.; Paterson, D. Determination of the oxidation state of $\mathrm{Cu}$ in substituted $\mathrm{Cu}$-In-Fe-bearing sphalerite via $\mu$-XANES spectroscopy. Am. Mineral. 2012, 97, 476-479. [CrossRef]

22. Cook, N.J.; Etschmann, B.; Ciobanu, C.L.; Geraki, K.; Howard, D.L.; Williams, T.; Rae, N.; Pring, A.; Chen, G.; Johannessen, B.; et al. Distribution and substitution mechanism of $\mathrm{Ge}$ in a Ge-(Fe)-bearing sphalerite. Minerals 2015, 5, 117-132. [CrossRef]

23. Ciobanu, C.L.; Cook, N.J.; Utsunomiya, S.; Pring, A.; Green, L. Focused ion beam-transmission electron microscopy application in ore mineralogy: Bridging micron and nanoscale observations. Ore Geol. Rev. 2011, 32, 6-31. [CrossRef]

24. Pfaff, K.; Koenig, A.; Wenzel, T.; Ridley, I.; Hildebrandt, L.H.; Leach, D.L.; Markl, G. Trace and minor element variations and sulfur isotopes in crystalline and colloform $\mathrm{ZnS}$ : Incorporation mechanisms and implications for their genesis. Chem. Geol. 2011, 286, 118-134. [CrossRef]

25. Belissont, R.; Boiron, M.C.; Luais, B.; Cathelineau, M. LA-ICP-MS analyses of minor and trace elements and bulk Ge isotopes in zoned Ge-rich sphalerites from the Noailhac-Saint-Salvy deposit (France): Insights into incorporation mechanisms and ore deposition processes. Geochim. Cosmochim. Acta 2014, 126, 518-540. [CrossRef] 
26. Bonnet, J.; Mosser-Ruck, R.; Caumon, M.-C.; Rouer, O.; Andre-Mayer, A.-S.; Cauzid, J.; Peifert, C. Trace element distribution $(\mathrm{Cu}, \mathrm{Ga}, \mathrm{Ge}, \mathrm{Cd}$ and $\mathrm{Fe})$ in sphalerite from the Tennessee MVT deposits, USA, by combined EMPA, LA-ICP-MS, Raman spectroscopy and crystallography. Can. Mineral. 2016, 54, 1261-1284. [CrossRef]

27. Frenzel, M.; Hirsch, T.; Gutzmer, J. Gallium, germanium, indium, and other trace and minor elements in sphalerite as a function of deposit type-A meta-analysis. Ore Geol. Rev. 2016, 76, 52-78. [CrossRef]

28. Goldmann, S.; Junge, M.; Wirth, R.; Schreiber, A. Distribution of trace elements in sphalerite and arsenopyrite on the nanometre-scale-Discrete phases versus solid solution. Eur. J. Mineral. 2019, 31, 325-333. [CrossRef]

29. Turneaure, F.S. The Bolivian Tin-Silver Province. Econ. Geol. 1971, 66, 215-225. [CrossRef]

30. Sugaki, A.; Ueno, H.; Shimada, N.; Kusachi, I.; Kenichiro, A.; Hayashi, K.; Kojima, S.; Sanjines, O.; Sanches, A.; Veralde, O. Geological Study of the polymetallic ore deposits in the Quechisla District Bolivia. Sci. Rep. Tohoku Univ. Third Ser. 1985, 16, 35-129.

31. Olivier, B. The Geology and Petrology of the Merelani Tanzanite Deposit, NE Tanzania. Unpublished. Ph.D. Thesis, University of Stellenbosch, Stellenbosch, South Africa, 2006; p. 322.

32. Wilson, W.E.; Saul, J.M.; Pardieu, V.; Hughes, R.W. The Merelani tanzanite Mines. Mineral. Rec. 2009, 40, 347-408.

33. Harrison, S.; Jaszczak, J.A.; Keim, M.; Rumsey, M.; Wise, M.A. Spectacular sulfides from the Merelani Tanzanite Deposit, Manyara Region, Tanzania. Mineral. Rec. 2014, 45, 553-570.

34. Hunter, B.A. Rietica-A Visual Rietveld Program. Int. Union Crystallogr. Comm. Powder Diffr. Newsl. 2000, 20. Available online: https://inis.iaea.org/search/search.aspx?orig_q=RN:31059005 (accessed on 7 February 2020).

35. Muller, W.; Shelley, M.; Miller, P.; Broude, S. Initial performance metrics of a new custom-designed ArF excimer LA-ICPMS system coupled to a two-volume laser-ablation cell. J. Anal. Atom. Spectrom. 2009, 24, 209-214. [CrossRef]

36. Wilson, S.A.; Ridley, W.I.; Koenig, A.E. Development of sulfide calibration standards for the laser ablation inductively-coupled plasma mass spectrometry technique. J. Anal. Atom. Spectrom. 2002, 17, 406-409. [CrossRef]

37. Paton, C.; Hellstrom, J.; Paul, B.; Woodhead, J.; Hergt, J. Iolite: Freeware for the visualisation and processing of mass spectrometric data. J. Anal. Atom. Spectrom. 2011, 26, 2508-2518. [CrossRef]

38. Woodhead, J.D.; Hellstrom, J.; Paton, C.; Hergt, J.M.; Greig, A.; Maas, R. A guide to depth profiling and imaging applications of LA-ICP-MS. In Laser-ablation-ICPMS in the Earth Sciences: Current Practices and Outstanding Issues; Sylvester, P.J., Ed.; Mineralogical Association of Canada, Short Course Series: Vancouver, BC, Canada, 2008; Volume 40, pp. 135-145.

39. Skinner, B.J. Unit -cell edges of natural and synthetic sphalerites. Am. Mineral. 1961, 46, 1399-1411.

40. Skinner, B.J.; Bethke, P.M. The relationship between unit-cell edges and composition of synthetic wurtzites. Am. Mineral. 1961, 46, 1382-1398.

41. Johan, Z. Indium and germanium in the structure of sphalerite: An example of coupled substitution with copper. Mineral. Petrol. 1988, 39, 211-235. [CrossRef]

42. Slater, E.T.; McDonald, A.M.; Kontak, D.J. Resolving primary and retrograde sulfide and sulfosalt textures in the epithermal Ag-Zn-Pb-Sn-rich Cortaderas zone, Pirquitas Mine, Argentina. Can. Mineral. 2019, 57, 117-143. [CrossRef]

43. Strunz, H.; Nickel, E.H. Strunz Mineralogical Tables, 9th ed.; E Schweizerbart'sche Verlagbunchhandlung: Stuttgart, Germany, 2001; p. 870.

44. Kisi, E.H.; Elcombe, M.M. Parameters for wurtzite structure of $\mathrm{ZnS}$ and $\mathrm{ZnO}$ using powder neutron diffraction. Acta Cryst. 1989, C45, 1867-1870. [CrossRef]

45. Pring, A.; Tarantino, S.; Tenailleau, C.; Etschmann, B.; Carpenter, M.A.; Zhang, M.; Liu, Y.; Withers, R.L. The crystal chemistry of Fe-bearing sphalerites: An infrared spectroscopic study. Am. Mineral. 2008, 93, 591-597. [CrossRef]

46. George, L.L.; Cook, N.J.; Ciobanu, C.L. Partitioning of trace elements in co-crystallized sphalerite-galena-chalcopyrite hydrothermal ores. Ore Geol. Rev. 2016, 77, 97-116. [CrossRef]

(C) 2020 by the authors. Licensee MDPI, Basel, Switzerland. This article is an open access article distributed under the terms and conditions of the Creative Commons Attribution (CC BY) license (http://creativecommons.org/licenses/by/4.0/). 